\title{
Antiviral drug sensitivity in ocular herpes simplex virus infection
}

\author{
M J Menage, E de Clercq, A van Lierde, V S Easty, J M Darville, S D Cook, D L Easty
}

\begin{abstract}
Thirty-nine herpes simplex virus (HSV) isolates were assayed for their sensitivity to 10 different antiviral agents. Of these $39 \mathrm{HSV}$ isolates 10 were cultured from recipient buttons obtained at penetrating keratoplasty in patients with inactive stromal scarring due to recurrent herpetic keratitis, 25 were cultured from patients with conjunctival and ulcerative ocular infections, and the remaining four were laboratory strains with known drug sensitivity patterns, thus providing controls for the experiment. All but one of the 35 clinical isolates of HSV were type 1 and all were sensitive to the 10 antiviral agents. A single type $\mathbf{2}$ isolate from a young man with recurrent conjunctivitis proved to be resistant to a number of the antiviral agents. Since many of the clinical isolates had been exposed to multiple and protracted antiviral drug treatment, it is suggested that antiviral drug resistance in type $1 \mathrm{HSV}$ ocular infection is not a significant problem.
\end{abstract}

Herpes simplex virus (HSV) resistance to antiviral drug treatment has long been suspected as a reason for therapeutic failure in herpetic keratitis. Failure to heal despite a protracted course of topical antiviral drug treatment has often been attributed to virus-drug resistance, but very few studies have looked at laboratory resistance of ocular herpetic infection. We have previously reported the isolation of $\mathrm{HSV}$ from $30 \%$ of corneal discs, removed during penetrating keratoplasty, of patients with scarring due to previous herpes simplex keratitis. ${ }^{1-3}$ The demonstration of virus in apparently inactive stromal scars, despite previous long-term treatment with multiple antiviral drugs, suggests possible resistance of these isolates.

This study reports the antiviral drug sensitivity of 10 such recipient button isolates. In addition 25 isolates cultured from other conjunctival and ulcerative ocular HSV infections were included to determine the general level of antiviral drug sensitivity in our ophthalmic practice. Four laboratory strains with known drug sensitivity patterns provided controls for the experiments.

\section{Patients and methods}

Ten HSV type 1 isolates from corneal discs of patients with inactive scarring due to herpetic keratitis were collected in Bristol and Glasgow. Twenty-five HSV isolates were grown in cell culture at the Bristol Public Health Laboratory from swabs taken from patients presenting with ocular infections to the casualty department of the Bristol Eye Hospital. These were from a variety of clinical conditions (Table 1). Details of previous antiviral therapy were recorded, where possible, for both groups of isolates (Table 2). All but one of the viral isolates were shown to be type 1 by restriction endonuclease analysis using Bst I and Pvu II. ${ }^{5}$ The only type 2 isolate was cultured from a young man with recurrent conjunctivitis and no history of genital infection.

Four laboratory strains were included as controls. The $\mathrm{SC}^{6} 6^{6}$ and $\mathrm{KOS}$ type 1 strains are known to be fully sensitive to all the antiviral agents. An in-vitro-derived acyclovir-resistant mutant of SC16 (kindly provided by Drs W A Blyth and T J Hill, Department of Microbiology, University of Bristol) and a multiply resistant type 2 strain, AR15, were also included. These provided both positive and negative controls for the experiment.

The 39 viral isolates were assayed for their sensitivity to ten antiviral agents (Table 3). These antiviral agents were selected on the basis of their known potential for the chemotherapy of HSV infections. ${ }^{7-9}$

The experimental method for assaying antiviral activity has previously been reported. ${ }^{10}$ All assays were carried out in confluent embryonic skin-muscle fibroblast $\left(\mathrm{E}_{6} \mathrm{SM}\right)$ cell cultures in

Table 1 Sources of viral isolates

\begin{tabular}{lc}
\hline Source & No of cases \\
\hline Culture of recipient corneal buttons & 10 \\
Dendritic ulcer (first presentation) & 11 \\
Dendritic ulcer (recurrence) & 6 \\
Follicular conjunctivitis & 7 \\
Lid vesicles & 1 \\
Control strains & 4 \\
Total & 39 \\
\hline
\end{tabular}

Table 2 Previous treatment of patients with antiviral drugs

\begin{tabular}{lcl}
\hline & Cormeal discs (10) & Casualty isolates (25) \\
\hline No previous treatment & 0 & 17 \\
Previous treatment & 10 & 8 \\
Antiviral drugs used & & \\
ACV & 5 & 3 \\
IDU & 5 & 2 \\
TFT & 4 & 0 \\
Ara-A & 5 & 0 \\
Unknown & 2 & 4 \\
\hline
\end{tabular}

Table 3 Antiviral agents used in the drug sensitivity determinations ${ }^{7}$

1 IDU: idoxuridine, 5-iodo-2'-deoxyuridine

2 TFT: trifluridine, 5-trifluoro-2'-deoxythymidine

3 Ara-A: vidarabine, 9-beta-D-arabinofuranosyladenine

4 ACV: acyclovir, 9-(2-hydroxyethoxymethyl) guanine

4 ACV: acyclovir, 9-(2-hydroxyethoxymethyl) guani

5 BVDU: (E)-5-(2-bromivinyl)-2'

EDU: 5-ethyl-2'-deoxyuridine
7 DHPG: 9-(1, 3-dihydroxy-2-propoxymethyl) guanine

7 DHPG: 9-(1, 3-dihydroxy-2-propoxymethyl)

PFA: foscarnet, phosphnoformate

10 (S)-HPMPA: (S)-9-(3-hydroxy-2-phosphonyl (methyoxypropyl) adenine 
Table 4 Mean $I D_{50}$ concentrations of antiviral agent for the HSV isolates

\begin{tabular}{|c|c|c|c|c|c|c|c|c|c|}
\hline \multirow{2}{*}{$\begin{array}{l}\text { Anti-viral } \\
\text { agents }\end{array}$} & \multicolumn{2}{|c|}{$\begin{array}{l}\text { Recipient corneal } \\
\text { buttons }\end{array}$} & \multicolumn{2}{|c|}{$\begin{array}{l}\text { Casualty infections } \\
\text { (type l) }\end{array}$} & \multirow{2}{*}{$\begin{array}{l}\text { Casualty } \\
\text { infection } \\
\text { (single } \\
\text { type 2) }\end{array}$} & \multirow{2}{*}{$\begin{array}{l}\text { SC16 lab } \\
\text { strain } \\
\text { (type 1) }\end{array}$} & \multirow{2}{*}{$\begin{array}{l}\text { ACV resistant } \\
\text { SC16 lab } \\
\text { strain } \\
\text { (type I) }\end{array}$} & \multirow{2}{*}{$\begin{array}{l}\text { AR15 lab } \\
\text { strain } \\
\text { (type 2) }\end{array}$} & \multirow{2}{*}{$\begin{array}{l}\text { KOS lab } \\
\text { strain } \\
\text { (typel) }\end{array}$} \\
\hline & Mean & Range & Mean & Range & & & & & \\
\hline IDU & $0 \cdot 20$ & $0.07-0.37$ & $0 \cdot 29$ & $0.07-0.70$ & $2 \cdot 00$ & 0.09 & 8.94 & $2 \cdot 83$ & $0 \cdot 30$ \\
\hline TFT & 1.55 & $0.53-2.00$ & 1.54 & $0.37-3.74$ & $20 \cdot 00$ & 0.37 & $2 \cdot 83$ & 20.00 & 2.00 \\
\hline ARA-A & $12 \cdot 2$ & $3 \cdot 7-20 \cdot 0$ & $9 \cdot 6$ & $1 \cdot 2-22 \cdot 1$ & $11 \cdot 8$ & $3 \cdot 7$ & $11 \cdot 8$ & $11 \cdot 8$ & $14 \cdot 6$ \\
\hline ACV & 0.04 & $0.02-0.07$ & 0.03 & $0.02-0.06$ & 0.02 & 0.02 & $20 \cdot 00$ & 0.02 & 0.04 \\
\hline BVDU & 0.03 & $0.01-0.04$ & 0.02 & $0.01-0.04$ & $167 \cdot 33$ & 0.01 & $141 \cdot 42$ & $>200 \cdot 00$ & 0.02 \\
\hline EDU & 1.59 & $0.53-2.00$ & 0.77 & $0 \cdot 20-2 \cdot 00$ & $2 \cdot 00$ & $0 \cdot 26$ & $141 \cdot 42$ & $2 \cdot 00$ & 0.70 \\
\hline DHPG & 0.002 & $0.002-0.003$ & 0.002 & $0.002-0.007$ & 0.002 & 0.002 & $1 \cdot 180$ & 0.002 & 0.002 \\
\hline CEDU & $0 \cdot 13$ & $0.02-0.20$ & $0 \cdot 14$ & $0.02-0.37$ & $4 \cdot 47$ & 0.05 & $>200 \cdot 00$ & $3 \cdot 74$ & 0.20 \\
\hline PFA & $73 \cdot 8$ & $28 \cdot 3-122 \cdot 5$ & 50.6 & $20 \cdot 0-122 \cdot 5$ & $70 \cdot 0$ & 70.0 & 70.0 & $70 \cdot 0$ & $46 \cdot 1$ \\
\hline HPMPA & 0.09 & $0.01-0.26$ & 0.06 & $0.01-0.20$ & 0.07 & 0.01 & 0.07 & 0.08 & 0.12 \\
\hline
\end{tabular}

microtitre trays. These were inoculated with 100 $\mathrm{CCID}_{50}\left(\mathrm{CCID}_{50}=50 \%\right.$ cell culture infective dose) of each virus for $1 \mathrm{~h}$ at $37^{\circ} \mathrm{C}$.

Sequentially decreasing concentrations of each test compound were then added to the virus infected cell cultures. Controls for each experiment consisted of cell cultures which had been inoculated only with the test virus. The viral cytopathic effect (CPE) in each culture was recorded microscopically. In the control the infected cell cultures' viral CPE was generally completed at three to four days after viral

\section{IDU (Idoxuridine)}

Viral Sensitivity

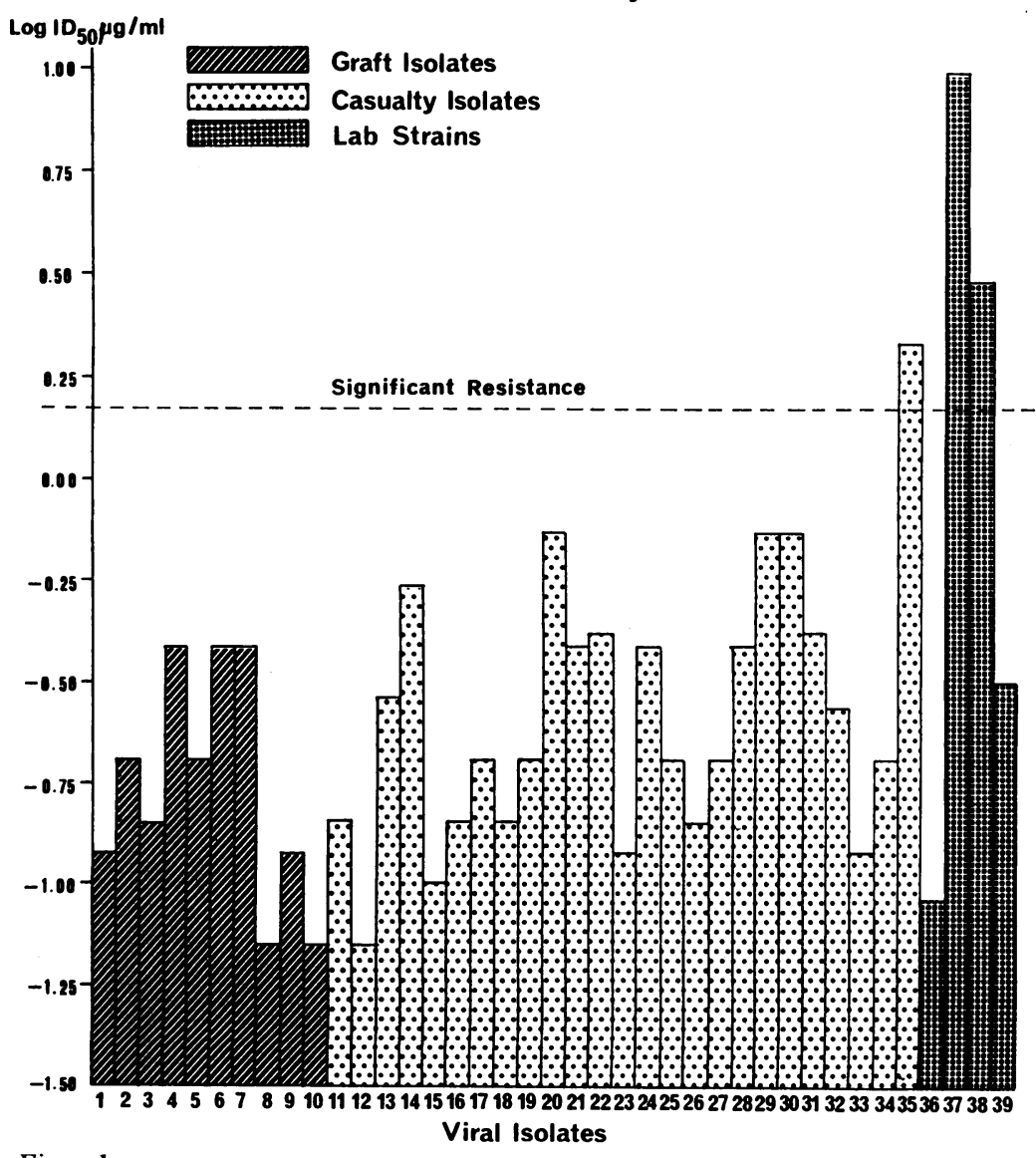

Figure 1

Figures 1-5 Sensitivity of the viral isolates to the five more commonly used antiviral drugs. Significant resistance is defined as a five-fold increase in the ID $D_{50}$ relative to the ID $D_{50}$ of the laboratory strain KOS (viral isolate no. 39). Viral isolate $35=$ type 2 isolate from recurrent conjunctivitis. Viral isolate $36=$ laboratory strain SC16. Viral isolate $37=$ acyclovir-resistant derivative of SC16. Viral isolate $38=$ type 2 laboratory strain AR15. Viral isolate $39=$ laboratory $K O S$.

Note that an arbitrary logarithmic scale is used; therefore sensitivity cannot be directly compared between separate graphs. inoculation. All experiments were repeated twice.

Antiviral drug sensitivity is expressed as the $\mathrm{ID}_{50}(50 \%$ of inhibitory dose), that is, the concentration of drug required to reduce the viral CPE by $50 \%$ at the time when complete cell destruction was noted in the control infected cell cultures.

\section{Results}

The mean $\mathrm{ID}_{50}$ obtained for each compound with viral isolate was calculated for the two experiments. All 10 of the viral isolates from corneal discs of inactive stromal scarring and the 24 type 1 viral isolates from ulcerative and conjunctival infections showed no significant resistance to any of the 10 antiviral agents. We found all type 1 clinical isolates were fully sensitive to the 10 antiviral agents (Table 4).

Significant resistance is defined as a five-fold increase in the $\mathrm{ID}_{50}$ relative to that for the KOS strain, since this control virus was known to be sensitive to all the antiviral agents used. Other workers using a similar method have defined resistance as high as a 10 -fold increase in the $\mathrm{ID}_{50}$ relative to that for the KOS strain.'

The single type 2 infection from a young man with recurrent conjunctivitis showed resistance to TFT, IDU, BVDU, and CEDU (see Table 3 for abbreviations), which was similar to the resistance pattern shown by the type 2 laboratory strain AR15.

Results for the four laboratory strains were as expected with the KOS and SC16 strains showing no evidence of resistance. The acyclovirresistant derivative of SC16 were resistant to ACV and also showed cross resistance to IDU, BVDU, EDU, CEDU, and DHPG. The type 2 AR15 strain showed resistance to TFT, IDU, BVDU, and CEDU.

The results for the five more familiar antiviral drugs are presented in Figs 1-5.

\section{Discussion}

Considerable attention has focused on the development of HSV resistance to antiviral drugs, most recently with the introduction of acyclovir to clinical practice. ${ }^{1213}$ Reports of acyclovir resistant clinical strains have largely been confined to immunosuppressed patients receiving high dose intravenous treatment, and sensitivity has returned on withdrawal of the acyclovir. ${ }^{1416}$

Report's of laboratory proved resistance to 
TFT (Trifluridine)

Viral Sensitivity

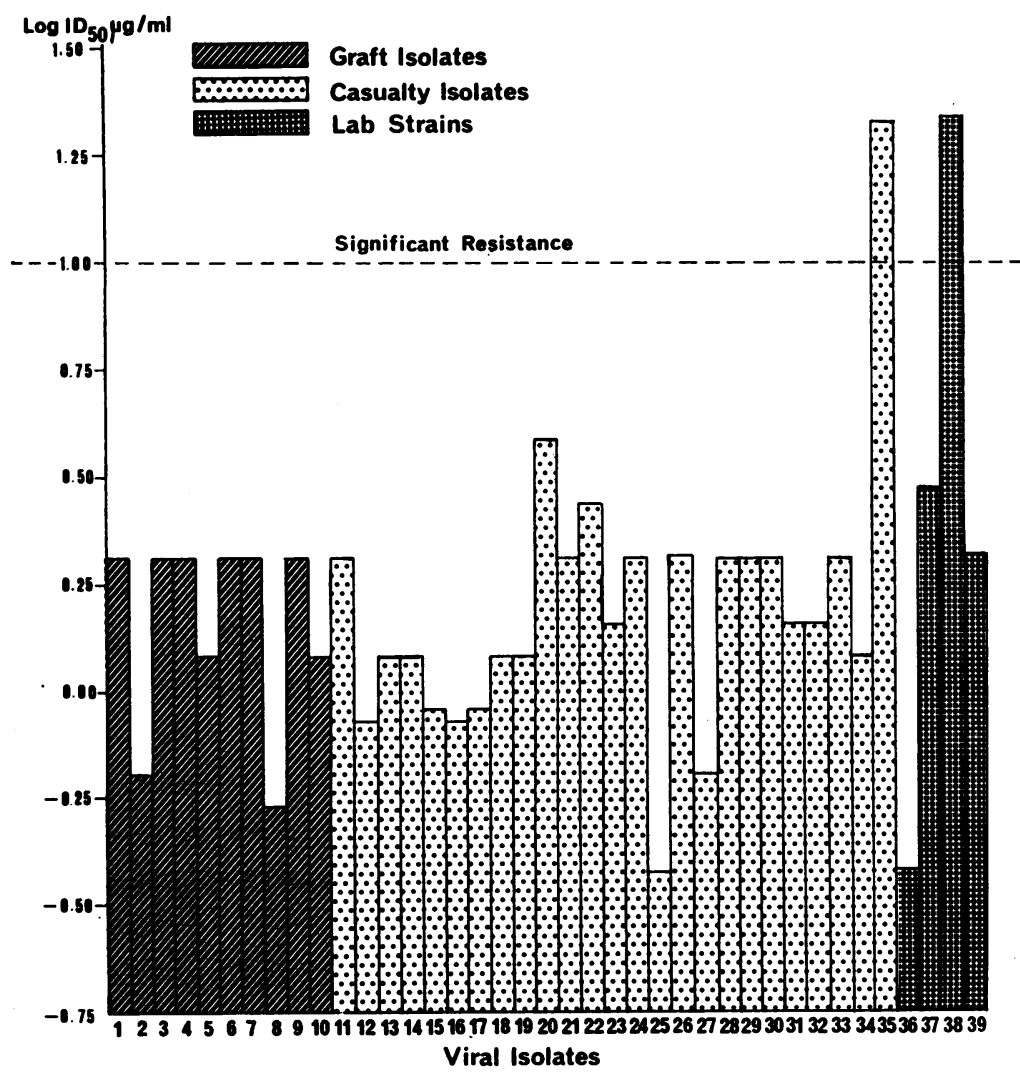

Figure 2

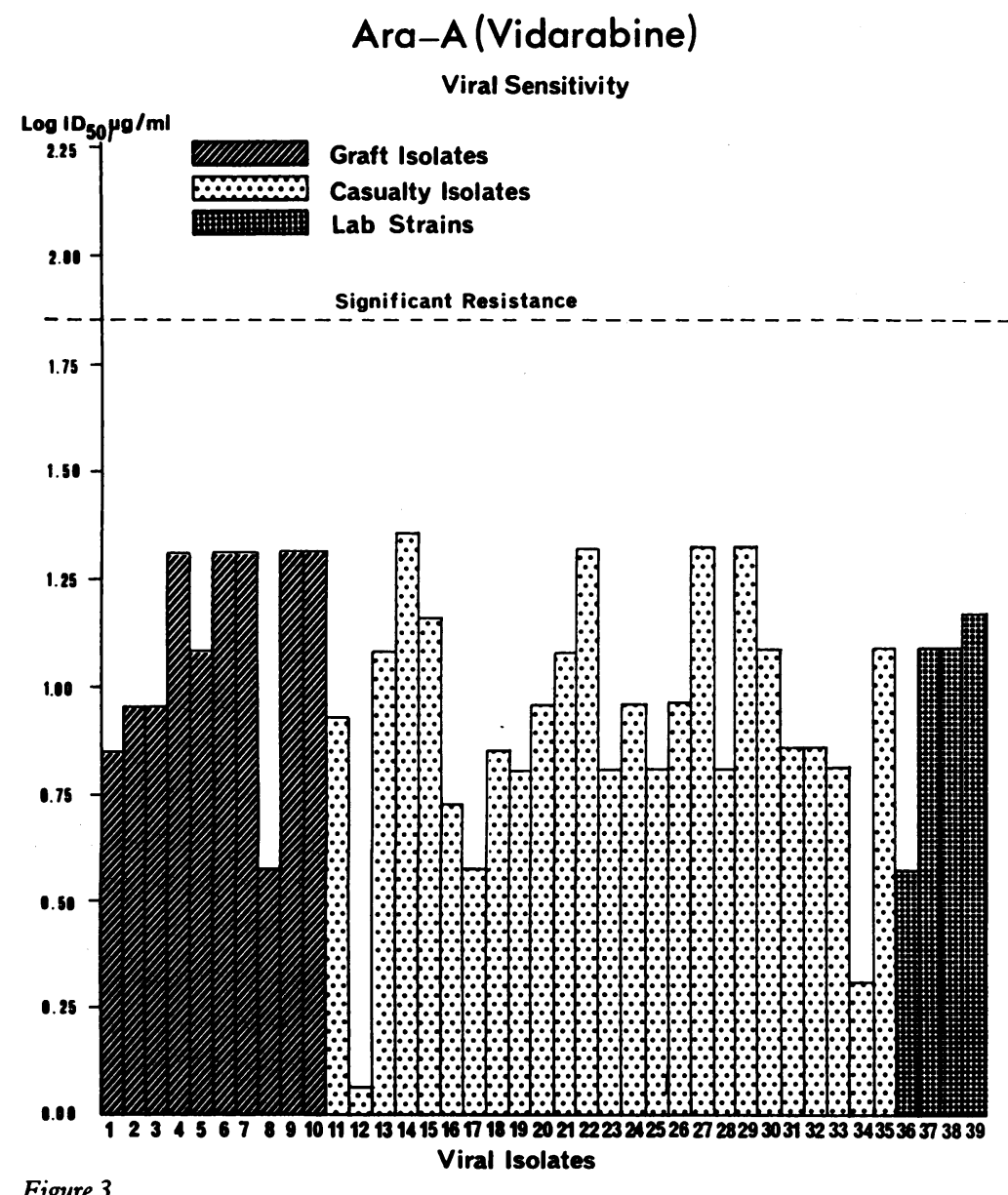

antivirals in ocular herpes simplex infection are very rare,${ }^{17}$ but failure to heal in clinical herpetic keratitis is a relatively common problem, with persistence of the infection despite apparently adequate treatment with a topical antiviral drug. A concept of 'treatment resistance' or 'clinical resistance' has been proposed in the situation where an ulcer fails to heal with apparently adequate treatment with one antiviral drug but responds well when another is used. ${ }^{18}{ }^{19} \mathrm{~A}$ complex definition of clinical resistance is necessary in order to try and exclude some of the many other causes of failure to respond to treatment. ${ }^{18}$ These include poor stromal penetration, poor compliance, inadequate treatment, toxicity, coexisting epithelial disease, and inappropriate use of steroids. Clinical resistance rates of $37 \%$ with IDU and $11 \%$ with Ara-A have been reported. ${ }^{17}$

The results of our experiments indicate there is little if any evidence of resistance of type 1 ocular isolates to the commonly used antiviral agents to support the relatively common clinical experience of failure of antiviral drug treatment of herpetic keratitis. This only serves to emphasis the need for adequate delivery of sufficient antiviral agent to the virus and the other multiple causes of clinical resistance.

This study developed from the isolation of HSV from inactive scarring in patients with long histories of herpetic keratitis. The patients had been subjected to multiple courses of antiviral drugs over many years. The lack of resistance of the isolates indicates that repeated exposure to antiviral drugs does not easily generate virus drug resistance in ophthalmic infection.

Resistance of HSV to antiviral drugs ${ }^{20}$ is mediated by two loci on the herpes virus genome, viral thymidine kinase and viral DNA polymerase. Thymidine kinase deficient mutants can easily be selected for in-cell culture and have occasionally been isolated from immunocompromised patients treated with acyclovir ${ }^{21}$ but show markedly diminished pathogenicity in laboratory animals. ${ }^{22}$ This is also the case in experimental ocular infections. ${ }^{23}$ ${ }^{24}$ It is postulated that, if such drug-resistant HSV mutants were to emerge in the corneal stroma of patients with herpetic keratitis, their low pathogenicity would make them unlikely either to establish trigeminal ganglion infection or subsequently to reactivate from a latent stage.

The HSV isolates from conjunctival and ulcerative infections presenting to the casualty department showed no significant resistance to any of the antiviral agents. The lack of resistance to a large number of commonly used antiviral agents in all the clinical type $1 \mathrm{HSV}$ infections would indicate a low incidence of virus-drug resistance in the vast majority of ocular HSV infections.

The only type $2 \mathrm{HSV}$ clinical isolate in our study showed resistance to TFT, IDU, BVDU, and CEDU but was fully sensitive to the other antiviral agents, including ACV. Even the most resistant isolates tested showed sensitivity to some of the commonly used antiviral agents.

Ocular type $2 \mathrm{HSV}$ infection is very rare, and no other similar isolates had been obtained at the time of the experiment. Some studies have 


\section{ACV (Acyclovir)}

Viral Sensitivity

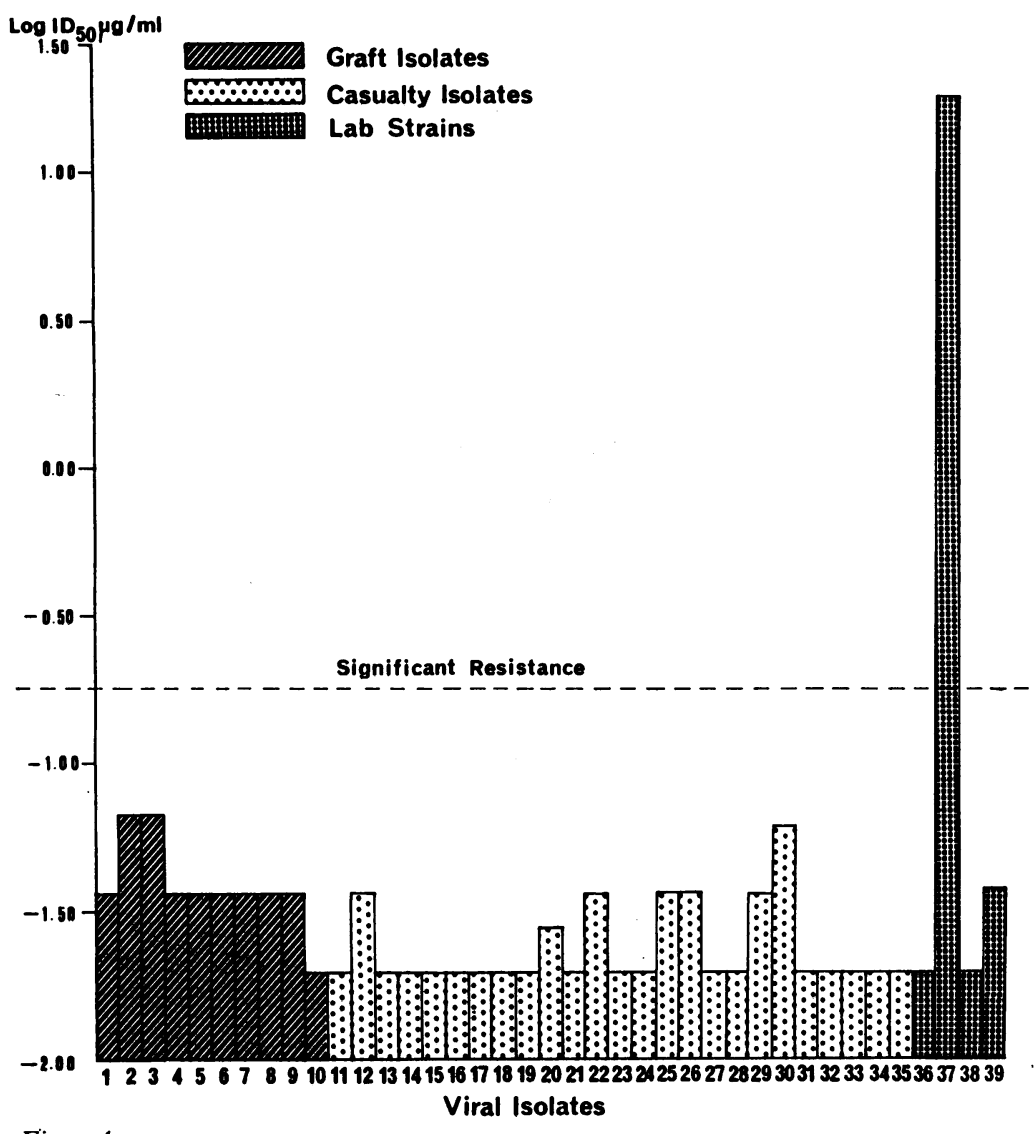

Figure 4

\section{BVDU (Bromovinyl-deoxyuridine) \\ Viral Sensitivity}

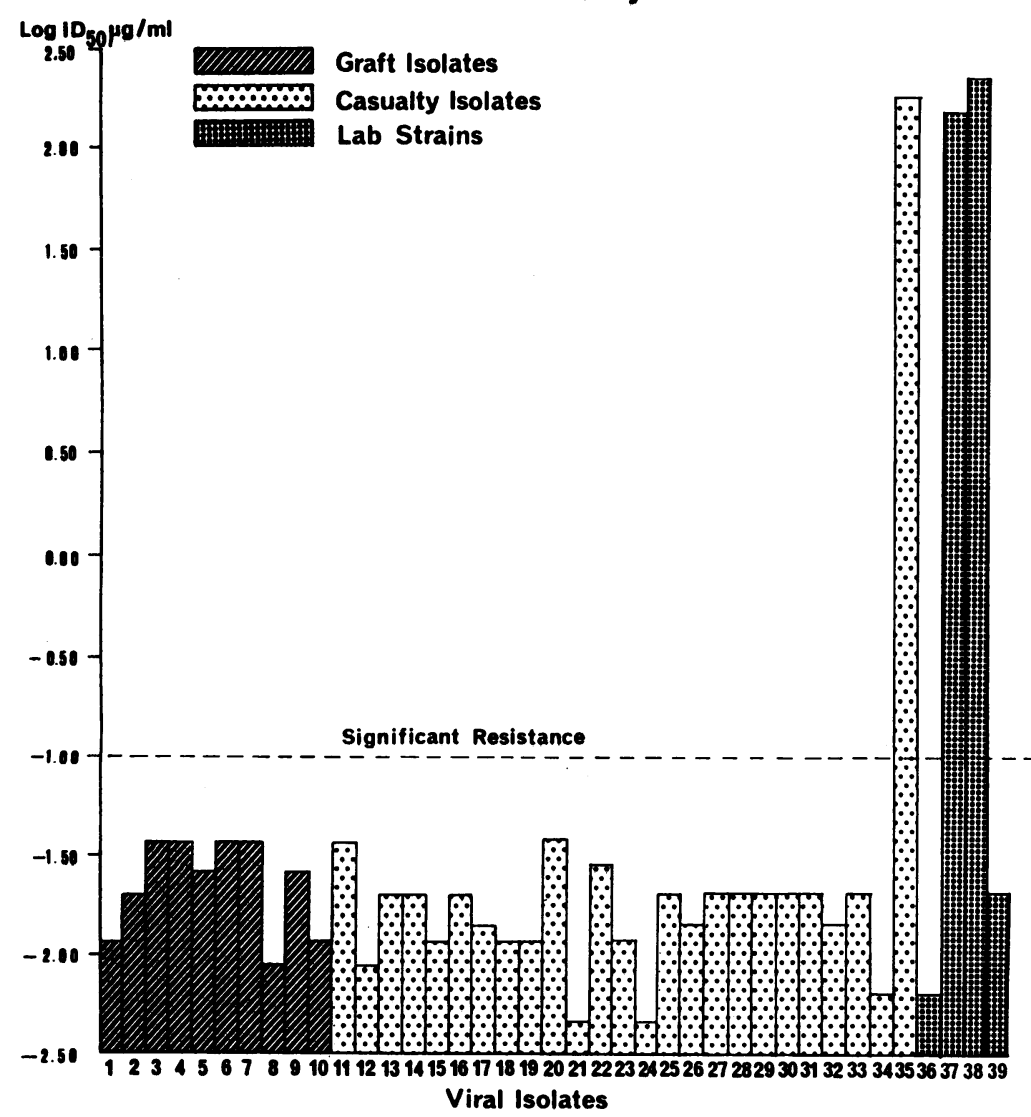

Figure 5 shown that type $2 \mathrm{HSV}$ isolates have higher $\mathrm{ID}_{50}$ values than type 1 isolates when tested for acyclovir sensitivity, ${ }^{14}$ and there is some evidence that breakthrough infections in patients on prophylactic acyclovir for genital type $2 \mathrm{HSV}$ infections show increased resistance ${ }^{16}$, but there is scant information on ocular infections.

It is unwise to draw any conclusions from a single result, but this obviously offers scope for further investigation into both the frequency of ocular type 2 herpetic infection and the level of resistance to antiviral drugs.

In conclusion, our results suggest that virusdrug resistance is not a significant problem in ocular type $1 \mathrm{HSV}$ infections.

1 Shimeld C, Tullo AB, Easty DL, Thomsitt J. Isolation of herpes simplex virus from the cornea in chronic stromal keratitis. Brf Ophthalmol 1982; 66: 643-7.

2 Tullo AB, Easty DL, Shimeld C, Stirling PE, Darville JM. Isolation of herpes simplex virus from corneal discs of patients with chronic stromal keratitis. Trans Ophthalmol patients with chronic strom

3 Easty DL, Shimeld C, Claoue CMP, Menage MJ. Herpes simplex virus isolation in chronic stromal keratitis: human and laboratory studies. Curr Eye Res 1987; 6: 69-74.

4 coos SD. PhD Thesis. University of Glasew: 1988.

5 Darville JM A miniaturised and simplified technique for typing and subtyping herpes simplex virus. $\mathcal{F}$ Clin Patho 1983; 36: 929-34.

6 Hill TJ, Field HJ, Blyth WA. Acute and recurrent infection with herpes simplex virus in the mouse: a model for studying latency and recurrent disease. 7 Gen Virol 1975 28: 341-53.

7 De Clercq E. Antiviral nucleoside analogs. ISI Atlas of Science: Pharmacology 1987; 1: 20-4.

8 De Clercq $E$. Recent advances in the search for selective antiviral agents. In: Testa $\mathrm{B}$, ed. Advances in drug research. London: Academic Press, 1988; 17: 1-59.

9 De Clercq E. Antiviral agents: facts and prospects. In: Reeves DS, Geddes AM, eds. Recent advances in infection. Edinburgh: Churchill Livingstone, 1989: 45-61.

10 De Clercq E, Descamps J, Verhelst G, Walker RT, Jones AS, Torrence PF, Shugar D. Comparative efficacy of antiherpes drugs against different strains of herpes simplex virus. F Infect Dis 1980; 141: 563-74.

11 Field $\mathrm{HJ}$. A perspective on resistance to acyclovir in herpes simplex virus. I Antimicrob Chem 1983; 12 (suppl B): 129-35.

12 Timbury MC. Acyclovir. Br Med f 1982; 285: $1223-4$.

13 Kaufman HE, Centifanto-Fitzgerald YM, Varnell ED Herpes simplex keratitis. Ophthalmology 1983; 90: 700-6.

4 Crumpacker C. Resistance of herpes simplex virus to anti-viral agents. Drugs 1983; 26: 373-7.

15 Dekker C, Nixon Ellis M, McLaren C, Hunter G, Rogers J Barry DW. Virus resistance in clinical practice. $\mathcal{F}$ Antimicro Chem 1983; 12: 137-52.

16 Dorsky DI, Crumpacker CS. Drugs five years later: acyclovir. Ann Intern Med 1987; 107: 859-74.

17 McGill JI, Ogilvie M. Viral drug resistance in herpes simplex ulceration. In: Trevor-Roper P, ed. VIth Congress of the ulceration. In: Trevor-Roper P, ed. VIth Congress of the European Society for Ophthat

18 McGill JI, Coster D, Frauenfelder T, Holt-Wilson AD, Williams $\mathrm{H}$, Jones BR. Adenine arabinoside in the management of herpetic keratitis. Trans Ophthalmol Soc UK 1975; 95: 246-9.

19 McGill JI, Tormey P. Use of acyclovir in herpetic ocular infection. Am F Med 1982; 20: 286-9.

$20 \mathrm{De}$ Clercq $\mathrm{E}$. Virus drug resistance: thymidine kinase deficien (TK-) mutants of herpes simplex virus. Therapeutic approaches. Ann 1st Super Sanita 1987; 23: 841-8.

21 Vinckier F, Boogaerts M, De Clerck D, De Clercq E. Chronic herpetic infection in an immunocompromised patient: herpetic infection in an immunocompromised patie

22 Field HJ, Darby G. Pathogenicity in mice of strains of herpes simplex virus which are resistant to acyclovir in vitro and in simplex virus which are resistant to acyclovir in vitro

23 Gordon YJ, Armstrong JA, Brown SI, Becker Y. The role of herpes virus type I thymidine kinase in experimental ocular infections. Am f Ophthalmol 1983; 95: 175-81.

24 Maudgal PC, De Clercq E. Huyghe P. Efficacy of (S)-HPMPA against thymidine kinase-deficient herpes simplex virus keratitis. Invest Ophthalmol Vis Sci 1987; 28: 243-8. 